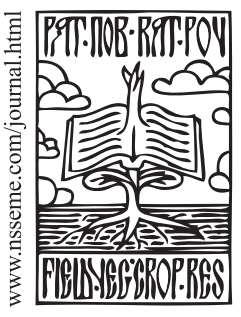

\title{
Effect of Microbiological Fertilizer and Soil Additive on Yield of Buckwheat (Fagopyrum esculentum Moench) Under High Altitude Conditions
}

\author{
Snežana Oljača • Željko Dolijanović • Mićo Oljača • Snežana Đorđević
}

\author{
received: 7 September 2012, accepted: 11 December 2012 \\ (c) 2012 IFVC \\ doi:10.5937/ratpov49-2528
}

\begin{abstract}
Summary: Effect of microbiological fertilizer (Slavol) and soil additives (zeolite and hydrogel) on buckwheat (Fagopyrum esculentum Moench) yield was investigated in this paper. Trial was set up in the village of Radijevići, Serbia in agroecological conditions of mountain Zlatar (altitude 1,065 m) during a two-year period 2009 and 2010. A randomized complete block design with four replications was set up. In organic cropping system three combinations of microbiological fertilizer (Slavol) with zeolite and hydrogel were used prior to sowing. Different combinations of the microbiological fertilizer and the soil additives gave positive results especially in the second year of the trial. The best combination in organic cropping system was Slavol+hydrogel with foliar application of the microbiological fertilizer, which resulted in the greatest yield of buckwheat and this treatment can be recommended to producers. Buckwheat performed very well under limited conditions of acidic soil on high altitude in organic cropping system and it can be recommended as a very suitable crop for organic producers.
\end{abstract}

Key words: buckwheat, cropping systems, fertilizing, grain yield, hydrogels, microbiological fertilizers, organic agriculture, organic crop production, soil additives

\section{Introduction}

Although not a major crop, buckwheat can be an important grain source for humans and livestock, feed crop for wildlife, an excellent source crop for honey bees, a smother crop for weeds, a cover crop in orchards, vineyards, and other crops. Buckwheat can be grown under many climatic conditions, planted almost anytime during the growing season, and on a wider variety of soil types than any other grain crop (Malešević et al, 2008). If climatic conditions favour grain development, it will produce a better crop than any other grain on infertile, poorly tilled soil, tolerates very acid soil conditions (Glamočija et al. 2011).

Therefore, buckwheat is very suitable for gowning in organic cropping system on high altitude plots (Oljača et al. 2010).

S. Oljača* • Ž. Dolijanović • M. Oljača • S. Đorđević

University of Belgrade, Faculty of Agriculture, Nemanjina 6,

11080 Belgrade, Serbia

e-mail: soljaca@eunet.rs
Buckwheat has been used both as food and traditional medicine. Buckwheat is cited as an origin plant of rutin, which is a kind of flavonol glycoside compound used to prevent oedema, haemorrhagic diseases and stabilizing high blood pressure (Omidbaigi \& Mastro 2004). It is the crop with very good influence on health and in Germany it was declared a medicinal plant of the year in 1999 (Gadžo 2009). Buckwheat flour applied as a component of gluten-free formulas improves the nutritional value and technological parameters of experimental gluten-free bread. Buckwheat flour enriches gluten-free bread with proteins and microelements, especially with copper and manganese, but also with iron and zinc. Therefore, the utilization of buckwheat flour both as a valuable nutrient and a factor improving technological properties of gluten-free bread can be highly recommended (Krupa-Kozak et al. 2011).

Acknowledgement: This study was carried out with funding from the Serbian Ministry of Education, Science and Technological Development, project TR - 31066 „Modern breeding of small grains for recent and future needs". 


\section{Materials and methods}

Buckwheat cultivar Novosadska was included in a complete randomized block design with four replications with sowing rate of $80 \mathrm{~kg} \mathrm{ha}^{-1}$. Trials were set up in Radijevići village $\left(43^{\circ} 23^{\prime}\right.$ $52^{\prime \prime} \mathrm{N}, 19^{\circ} 52^{\prime} 33^{\prime \prime}$ E) under agroecological conditions of hilly-mountainous region of Zlatar (altitude 1,065 m) in 2009 and 2010. Sowing was performed on June 11 and June 10 for growing seasons of 2009 and 2010, respectively, and harvesting when $75 \%$ of grains were mature (September 20 and 18). Weather data covering the two seasons were collected from the nearest meteorological station Zlatibor (Fig. 1). The season 2010 was characterized by higher temperatures then in 2009 but also higher precipitation sum when compared to long-term average. Average temperature during vegetative period in 2009 was $16.6^{\circ} \mathrm{C}$ and in 2010 it was $19.7^{\circ} \mathrm{C}$. However, precipitation sum in the same periods was similar - $584 \mathrm{~mm}$ in 2009 and 589 $\mathrm{mm}$ in 2010.

Plot size was $12 \mathrm{~m}^{2}$ and the soil was very acid with high content of humus, high reserve of mineral $\mathrm{N}$, and very low content of $\mathrm{P}$ (Table 1). Soil additives (zeolite $2.67 \mathrm{t} \mathrm{ha}^{-1}$ and hydrogel $20 \mathrm{~kg} \mathrm{ha}^{-1}$ ) and microbiological fertilizer Slavol $\left(71 \mathrm{ha}^{-1}\right)$ were inoculated on seeds and their combinations were applied prior to sowing. Half of each plot was treated with foliar microbiological fertilizer Slavol during crop growing period. The microbiological fertilizer Slavol is a universal, certified fertilizer and can be used in organic agriculture. This is a natural product without any chemical additives, thus having a positive

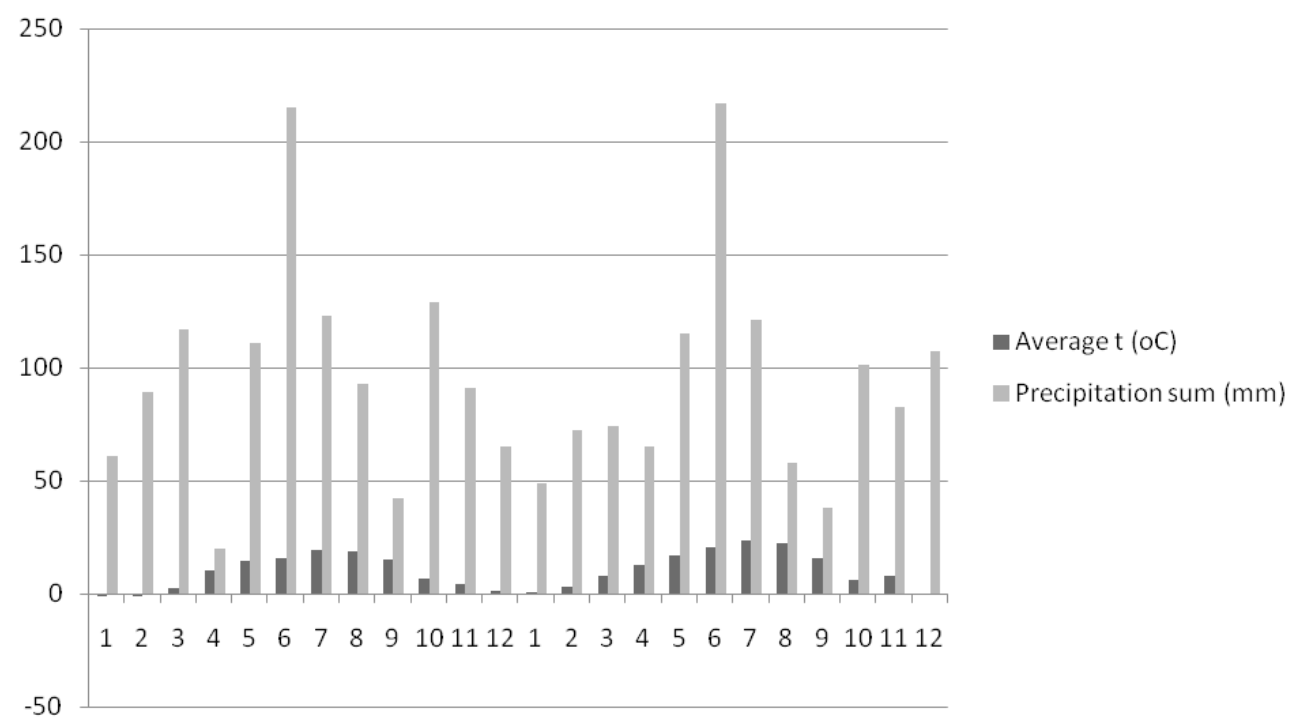

Figure 1. Meteorological conditions for Zlatibor in 2009 and 2010

Grafik 1. Meteorološki uslovi za Zlatibor u 2009. i 2010. godini

Table 1. Soil properties on experimental plots

Tabela 1. Osobine zemljišta na eksperimetalnim parcelama

\begin{tabular}{|c|c|c|c|c|c|c|c|c|c|c|c|}
\hline \multirow{3}{*}{$\begin{array}{l}\text { Depth } \\
\text { Dubina } \\
(\mathrm{cm})\end{array}$} & \multicolumn{2}{|c|}{$\mathrm{pH}$} & $\mathrm{CaCO}_{3}$ & Humus & $\begin{array}{c}\text { Total } \\
\mathrm{N}\end{array}$ & \multirow{3}{*}{$\mathrm{C} / \mathrm{N}$} & \multicolumn{3}{|c|}{$\begin{array}{c}\text { Available N } \\
\text { Pristupačni N }\end{array}$} & \multicolumn{2}{|c|}{$\begin{array}{c}\text { Available } \\
\text { Pristupačni } \\
\text { (Al-method) }\end{array}$} \\
\hline & $\mathrm{HO}$ & $\mathrm{nKCl}$ & \multirow{2}{*}{\multicolumn{3}{|c|}{$\%$}} & & $\mathrm{NH}_{4}^{+}$ & $\mathrm{NO}_{3}$ & Sum & $\mathrm{P}_{2} \mathrm{O}_{5}$ & $\mathrm{~K}_{2} \mathrm{O}$ \\
\hline & & & & & & & \multicolumn{3}{|c|}{$\mathrm{mg} / \mathrm{kg}$} & \multicolumn{2}{|c|}{$\mathrm{mg} / 100 \mathrm{~g}$} \\
\hline $0-10$ & 5.04 & 4.10 & - & 5.73 & 0.286 & 11.6:1 & 17.5 & 17.5 & 35.0 & 1.3 & 14.1 \\
\hline $20-40$ & 4.81 & 4.07 & - & 4.35 & 0.220 & & 18.2 & 11.9 & 30.1 & 0.5 & 8.6 \\
\hline
\end{tabular}


influence on plants, soil and the environment. The soil additives (zeolite and hydrogel) are also allowed for application in organic agriculture. Zeolites can act as water moderators, in which they will absorb up to $55 \%$ of their weight in water and slowly release it under the plant's demand. This property can prevent root rot and moderate drought cycles.

Grain yield of buckwheat $\left(\mathrm{tha}^{-1}\right)$ was determined after harvest. The samples included 30 randomly selected plants per plot for determination of 1,000 kernel weight (TKW).

The data were processed by ANOVA, using LSD test for comparison of means.

\section{Results and Discussion}

On the basis of two-year results it is obvious that meteorological conditions had very significant influence on buckwheat productivity. The second season 2010 had weather pattern more favourable for the buckwheat production with mild and moist winter and warm but rainy spring and summer.
TKW was appreciably increased in 2010 compared to 2009, while different combinations of the microbiological fertilizer and the soil additives had no significant influence on this parameter (Table 2). Only in interactions year with fertilization significant differences were recorded. The smallest TKW was noticed in the variant Slavol inoc. + Slavol fol. 23.95g and the largest $(26.2 \mathrm{~g})$ on the variants: Slavol inoculation, Control + Slavol fol. and Control.

Large differences between temperatures had an effect on significant differences between yields in the two seasons. Significantly greater buckwheat yield was recorded in 2010. Different combinations of the microbiological fertilizer and soil additives gave positive results on grain yield compared with the control. The best combination in two-year average in organic cropping system was Slavol inoc. + hydrogel with foliar application of the microbiological fertilizer, which resulted with the greatest yield of buckwheat $\left(1.538 \mathrm{t} \mathrm{ha}^{-1}\right)$. It is obvious that foliar application of the microbiological fertilizer has very positive influence on buckwheat

Table 2. The effect of microbiological fertilizer and soil additives on TKW and yield of buckwheat Tabela 2. Uticaj mikrobiološkog đubriva i opemenjivača zemljišta na masu 1000 zrna i prinos heljde

\begin{tabular}{|c|c|c|c|c|c|c|c|c|}
\hline \multirow{2}{*}{\multicolumn{3}{|c|}{ Variant / Varijanta }} & \multicolumn{2}{|c|}{$\begin{array}{c}\text { TKW }(\mathrm{g}) \\
\text { Masa } 1000 \text { zrna }\end{array}$} & \multirow{2}{*}{$\begin{array}{l}\text { Average } \\
\text { Prosek }\end{array}$} & \multicolumn{2}{|c|}{$\begin{array}{c}\text { Yield }\left(\mathrm{t} \mathrm{ha}^{-1}\right) \\
\text { Prinos }\end{array}$} & \multirow{2}{*}{$\begin{array}{l}\text { Average } \\
\text { Prosek }\end{array}$} \\
\hline & & & 2009. & 2010. & & 2009. & 2010. & \\
\hline \multicolumn{3}{|c|}{ Control } & 24.6 & 26.2 & 25.40 & 1.16 & 1.38 & 1.271 \\
\hline \multicolumn{3}{|c|}{ Control + Slavol fol. } & 25.8 & 26.2 & 26.00 & 1.59 & 1.44 & 1.519 \\
\hline \multicolumn{3}{|c|}{ Slavol inoculation } & 25.2 & 26.2 & 25.70 & 1.16 & 1.50 & 1.335 \\
\hline \multicolumn{3}{|c|}{ Slavol inoc. + Slavol fol. } & 23.95 & 26.0 & 24.97 & 1.45 & 1.33 & 1.394 \\
\hline \multicolumn{3}{|c|}{ Slavol inoc.+ Zeolite } & 25.65 & 26.1 & 25.88 & 1.15 & 1.27 & 1.196 \\
\hline \multicolumn{3}{|c|}{$\begin{array}{l}\text { Slavol inoc. }+ \text { Zeolite }+ \\
\text { Slavol fol. }\end{array}$} & 25.8 & 26.0 & 25.90 & 1.40 & 1.35 & 1.381 \\
\hline \multicolumn{3}{|c|}{ Slavol inoc.+ Hydrogel } & 25.85 & 26.0 & 25.93 & 1.14 & 1.48 & 1.316 \\
\hline \multicolumn{3}{|c|}{$\begin{array}{l}\text { Slavol inoc. }+ \text { Hydrogel }+ \\
\text { Slavol fol. }\end{array}$} & 25.35 & 26.1 & 25.73 & 1.61 & 1.45 & 1.538 \\
\hline \multicolumn{3}{|c|}{ Average / Prosek } & 25.28 & 26.10 & 25.69 & 1.335 & 1.402 & 1.369 \\
\hline \multirow{5}{*}{ LSD } & & TKW & \multicolumn{6}{|c|}{ Yield } \\
\hline & & 0.05 & \multicolumn{2}{|c|}{0.01} & \multicolumn{3}{|c|}{0.05} & 0.01 \\
\hline & A & 0.499 & \multicolumn{2}{|c|}{0.685} & \multicolumn{3}{|c|}{0.059} & 0.081 \\
\hline & & 0.998 & \multicolumn{2}{|c|}{1.369} & \multicolumn{3}{|c|}{0.118} & 0.161 \\
\hline & $\mathrm{AB}$ & 1.412 & & & & 0.166 & & 0.228 \\
\hline
\end{tabular}


productivity in both years of the trial. In variant of the control with no fertilizers but with foliar application of the microbiological fertilizer we obtained approximately the same yield such as in the best combinations of fertilizers. This result is very much compatible with the results of Kovačević et al. (2009, 2011) where significantly greater yields of different species of wheat (Triticum spelta, T. durum, T. aestivum ssp. compactum) and other small grains were obtained in similar treatments. It is also in accordance with the results of experiment with winter rye (Oljača et al., 2010) in organic cropping system.

The highest yield improvement achieved by application of the bacterial fertilizer was in the variant Slavol inoc. + Hydrogel + Slavol fol. in 2009 with $1.61 \mathrm{t} \mathrm{ha}^{-1}$ and this combination can be recommended to producers (Table 2). In the same treatment in the trial with winter rye the best crop productivity was obtained (Oljača et al 2010). Yield in the control was not significantly lower in 2010 compared with other treatments thanks to high reserve of nitrogen and humus in the soil. It is important to stress that soil on experimental plots was not used for agriculture for a long period of time retaining fertility and enabling greater crop productivity. Natural microbiological fertilizer such as Slavol containing products of bacterial fermentation, natural vitamins, enzymes and growth stimulators helps the plant to bind useful substances from the soil more effectively, exploiting natural resources to the maximum, without polluting the soil. It aids the nutrition of plants by converting organic and hardly soluble compounds into accessible forms which are directly delivered to the root systems.

To our knowledge, the results of this experiment are the first report on the effect of microbiological fertilizer and soil additive on buckwheat in organic cropping system in our country. For organic producers, especially in the neglected hilly-mountainous regions of Serbia, these results might be helpful.

\section{Conclusions}

According to the presented results of the research of different fertilizer combinations in organic cropping system for buckwheat during the seasons 2009 and 2010, the following conclusions can be reached:
- The second season 2010 had weather pattern more favourable for the buckwheat production.

- Organic cropping system under conditions of Zlatar hilly region gave significantly greater yield compared with the control especially in 2009 growing season.

- The best combination in two-year average in organic cropping system was Slavol inoc. + hydrogel with foliar application of the microbiological fertilizer, which resulted with the greatest yield of buckwheat.

- It is obvious that foliar application of the microbiological fertilizer has very positive influence on buckwheat productivity in both years of the trial, which leads toward conclusion that this treatment can be recommended not only for buckwheat but the other alternative small grains.

- On the other hand, buckwheat performed very well under limited conditions of acid soil on high altitude in organic cropping system and it can be recommended as very suitable crop for organic producers.

\section{References}

Gadžo,D. (2009). Savremene tehnologije uorganskojpoljoprivredi: Uzgoj heljde. Retrieved from http://www. organsko. ba/ index. php?option=com_content $\&$ view=article $\&$ id $=23$ : uzgojheljde\&catid=12: pisani-materijali\&Itemid $=25$

Glamočlija, D.N., Glamočlija, M., \& Cvijanović, G. (2011). Heljda - privredni značaj, poreklo i površine, biološke i morfološke osobine, uslovi uspevanja, tehnologija proizvodnje, prerada zrna, priprema jela od zrna i brašna. Beograd: Poljoprivredni fakultet.

Kovačević, D., Dolijanović, Ž., Oljača, S., \& Milić, V. (2009). Prinos nekih alternativnih vrsta pšenice u organskoj proizvodnji. Journal of Scientific Agricultural Research, 70(3), 17-25. Retrieved from http://scindeks. ceon.rs/article. aspx?artid=0354-56950903017K0

Kovačević, D., Oljača, S., \& Dolijanović, Ž. (2011). Grain yields of alternative small grains in organic field production. In: Proceedings of 46th Croatian and 6th International Symposium on Agriculture, Opatija. 80-83.

Krupa-Kozak, U., Wronkowska, M., \& Soral-Šmietana, M. (2011). Effect of buckwheat flour on microelements and proteins contents in gluten-free bread. Czech J. Food Sci., 29, 103-109.

Malešević, M., Jaćimović, G., Babić, M., \& Latković, D. (2008). Upravljanje proizvodnjom ratarskih kultura. In B. Lazić \& M. Babović (Eds.), Organska poljoprivreda. (pp. 153-226). Novi Sad: Naučni institut za ratarstvo i povrtarstvo.

Oljača, S.I., Dolijanović, Ž.K., Glamočlija, Đ.N., Đorđević, S.S., \& Oljača, J.M. (2010). Prinos zrna heljde u organskom sistemu gajenja. In: Zbornik radova I nučnog simpozijuma agronoma sa međunarodnim učešćem, AGROSYM, Jahorina. $67-72$. 
Oljača, S.I., Dolijanović, Ž.K., Glamočlija, Đ.N., Đorđević, S.S., \& Oljača, J.M. (2010). Productivity of winter rye in organic vs. conventional cropping system. Journal of Agricultural Sciences, 55(2), 123-129. Retrieved from http://scindeks.ceon.rs/article.aspx?artid=1450$81091002123 \mathrm{O} 0$
Omidbaigi, R., \& Mastro, G. (2004). Influence of sowing time on the biological behaviour, biomass production, and rutin content of buckwheat (Fagopyrum esculentum Moench). Italian J of Agron, 8, 47-50.

\title{
Uticaj mikrobiološkog đubriva i oplemenjivača zemljišta na prinos heljde (Fagopyrum esculentum Moench) u uslovima veće nadmorske visine
}

\author{
Snežana Oljača • Željko Dolijanović • Mićo Oljača • Snežana Đorđević
}

Izvod: U ovom radu je ispitivan uticaj mikrobiološkog đubriva (Slavol) i oplemenjivača zemljišta (zeolita i hidrogela) na prinos heljde (Fagopyrum esculentum Moench). Ogled je postavljen u selu Radijevići u agroekološkim uslovima planine Zlatar na nadmorskoj visini od 1.065 m tokom dvogodišnjeg perioda 2009. i 2010. Ogled je postavljen po slučajnom blok sistemu u četiri ponavljanja. U organskom sistemu gajenja su primenjene tri kombinacije mikrobiološkog đubriva sa zeolitom i hidrogelom pre setve useva. Sve varijante đubrenja su dale pozitivne rezultate u odnosu na prinos, naročito u drugoj godini istraživanja. Najbolja kombinacija u organskom sistemu gajenja je bila varijanta Slavol+hydrogel sa folijarnom primenom mikrobiološkog đubriva Slavola, koja je dala i najveći prinos heljde. Gajenje heljde pod limitiranim uslovima kiselog zemljišta na većoj nadmorskoj visini u organskom sistemu gajenja se pokazalo opravdanim i može se preporučiti proizvođačima.

Ključne reči: heljda, hidrogel, đubrenje, mikrobiološko đubrivo, oplemenjivači zemljišta, organska poljoprivreda, organska proizvodnja, prinos zrna, sistemi uzgajanja bilja 